\title{
Strategi Pengembangan Bank Sampah Sahdu Skala Kelurahan di Desa Tanimulya Kabupaten Bandung Barat
}

\author{
Yulianti Pratama $^{1 *}$, Muhammad Rizki Kurniawan ${ }^{2}$ \\ ${ }^{1,2}$ Teknik Lingkungan, Institut Teknologi Nasional, Bandung \\ *Koresponden email: yulianti@itenas.ac.id
}

Diterima: 7 Desember 2021

Disetujui: 5 Januari 2022

\begin{abstract}
Out of four waste banks in the Tanimulya Village, Sahdu Waste Bank is the only proper waste bank in operation. Based on the 2019 West Bandung District's Environmental Agency (Dinas Lingkungan Hidup $\&$ Kebersihan) Strategic Plan, which stated the target in 2022, that it needs to reduce 10\%, from the current $8 \%$ reduction of the waste generation through the solid waste management and waste bank facilites, prior to the landfill. One of the efforts that can be done is through the development of the Sahdu Waste Bank from the hamlet scale to the urban village scale by using the Waste Bank Indexing Method. Assessing the existing condition with the waste bank index, identification and compiling the recommendation towards parameters that need improvement. Based on the results of the assessment, a score of 53.2 (out of 100, and is considered as fairly good category), reveals 14 sub indicator that can be improved, which consist of 6 Sub Indicator of Management System, 6 Sub Indicator of Operational System, and 2 Sub Indicator of Waste Bank Facility. The value of the Sahdu Waste Bank can be increased to 88.3 (out of 100, and is considered as very good), which generates the reduction of $266.67 \%$ of waste, equal to 4 ton/month from $150 \mathrm{~kg} / \mathrm{month}$. That would make Sahdu Waste Bank contributes 1.6\% from the reduction target of $10 \%$ for the West Bandung District waste.
\end{abstract}

Keywords: waste bank, development, strategy, waste bank indexing method, reduction

\section{Abstrak}

Bank Sampah Sahdu merupakan satu-satunya bank sampah yang beroperasi dari empat bank sampah yang ada di Desa Tanimulya. Berdasarkan Rencana Strategis Dinas Lingkungan Hidup Kabupaten Bandung Barat Tahun 2019, perlu dilakukan pengurangan sampah sebelum dibawa ke tempat pemrosesan akhir sebesar 10\% pada Tahun 2022 melalui Tempat Pengelolaan Sampah Terpadu dan bank sampah, saat ini tingkat pengurangan baru 8\%. Salah satu upaya yang dapat dilakukan adalah melalui pengembangan Bank Sampah Sahdu dari skala RW menjadi skala Kelurahan dengan menggunakan Metode Indeks Bank Sampah. Dilakukan penilaian perbandingan terhadap kondisi eksisting dengan indeks bank sampah, selanjutnya direncanakan pengembangan berdasarkan hasil identifikasi dan rekomendasi terhadap parameter yang perlu ditingkatkan. Berdasarkan hasil penilaian diperoleh nilai sebesar 53,2 (dari 100 dengan kategori cukup baik), sehingga dilakukan pengembangan terhadap 14 sub indikator penilaian dari komponen, yaitu sistem manajemen sebanyak 6 sub indikator, sistem operasional sebanyak 6 sub indikator, dan fasilitas bank sampah sebanyak 2 sub indikator. Melalui pengembangan tersebut nilai Bank Sampah Sahdu dapat ditingkatkan menjadi 88,3 (skala 100 dengan kategori sangat baik) dengan tingkat pengurangan sampah menjadi 4 ton/bulan dari $150 \mathrm{~kg} / \mathrm{bulan}$ yaitu sebesar 266,67\%. Kontribusi Bank Sampah Sahdu terhadap pengurangan sampah adalah sebesar 1,6\% dari target $10 \%$ untuk seluruh Kabupaten Bandung Barat.

Kata Kunci: bank sampah, pengembangan, strategi, metode indeks bank sampah, reduksi

\section{Pendahuluan}

Menurut Peraturan Menteri Lingkungan Hidup dan Kehutanan (Permen LHK) No.13 Tahun 2012, bank sampah adalah tempat pemilahan dan pengumpulan sampah yang dapat didaur ulang atau digunakan kembali sehingga menghasilkan nilai ekonomis [1]. Peraturan ini bertujuan sebagai acuan atau pedoman kepada masyarakat untuk melaksanakan kegiatan Reduce, Reuse dan Recycle (3R) melalui bank sampah, dimana kegiatan $3 R$ tersebut dilaksanakan terhadap sampah rumah tangga dan sampah sejenis rumah tangga dengan tujuan untuk mengurangi sampah di sumber.

Perencanaan pengembangan Bank Sampah Sahdu (BSS) memiliki peran yang sangat penting untuk mengurangi timbulan sampah di sumber, yang melibatkan masyarakat dalam pengelolaannya [2] untuk mencapai target reduksi sampah yang ditetapkan oleh Pemerintah Daerah [3]. Sementara berdasarkan hasil 
wawancara dengan pengurus BSS arti nama Bank Sampah Sahdu, yaitu "Sahdu" sendiri merupakan singkatan dari "Sampah jadi Duit". Pengelolaan yang seperti bank, dimana sampah yang terkumpul ditimbang dan dinilai dengan sejumlah uang [4]. Hal ini sejalan dengan konsep ekonomi sirkuler, selain akan mendorong pemberdayaan ekonomi masyarakat sekitar [5], juga akan meningkatkan efisiensi penggunaan sumber daya fosil melalui daur ulang plastik [6].

Timbulan sampah harian Kabupaten Bandung Barat pada Tahun 2017 adalah 304 ton/hari dimana 102 ton berasal dari Kecamatan Ngamprah berdasarkan Kementerian Lingkungan Hidup dan Kehutanan Tahun 2018 [7]. Lokasi BSS terletak di Desa Tanimulya di Kecamatan Ngamprah, yang memiliki jumlah penduduk tertinggi yaitu pada Tahun 2017 adalah sebanyak 37.467 jiwa [8], yang berpotensi untuk melibatkan masyarakat dalam pengelolaan sampah sebagai nasabah dari BSS.

Berdasarkan Rencana Strategis Dinas Lingkungan Hidup Kabupaten Bandung Barat Tahun 2018, pengurangan sampah yang dilakukan baru mencapai 8\% sehingga ditargetkan pada tahun 2022 Pemerintah Kabupaten Bandung Barat akan melakukan pengurangan sebesar 10\% melalui Tempat Pengelolaan Sampah Terpadu dan bank sampah [3]. Sehingga untuk pemenuhan terhadap target pengurangan sampah tersebut, kontribusi BSS perlu ditingkatkan. Salah satu upaya yang dilakukan adalah dengan melakukan pengembangan bank sampah yang sebelumnya berskala RW menjadi bank sampah skala kelurahan. Hal ini juga diharapkan akan berkontribusi terhadap target nasional pengurangan sampah plastik sebesar $70 \%$ pada tahun 2025 [9], karena saat ini baru mencapai 10\% [10].

\section{Metode Penelitian}

\section{Lokasi Penelitian}

Lokasi penelitian dilakukan di BSS yang berada di Komplek Puri Cipageran 2, RT 02/ RW 22 Kecamatan Ngamprah Kabupaten Bandung Barat. Metode perencanaan dalam penelitian ini memiliki beberapa tahap sebagai berikut:

\subsection{Tahap Persiapan}

Perencanaan pengembangan BSS ini dilakukan melalui tahap persiapan yang terdiri dari pencarian studi literatur yang digunakan untuk mencari informasi dalam bentuk teori, standar serta hasil penelitian sebelumnya serta peraturan yang berlaku terkait pengembangan bank sampah.

\subsection{Tahap Pengumpulan Data}

Data primer merupakan data yang diperoleh melalui obseravasi langsung di lapangan yaitu data terkait sistem manajemen bank sampah, sistem operasional bank sampah dan fasilitas yang terdapat di bank sampah. Selanjutnya data sekunder merupakan data yang didapatkan dari acuan yang digunakan, seperti Peraturan Menteri Lingkungan Hidup Nomor 13 Tahun 2012 Tentang Pedoman Pelaksanaan Reduce, Reuse, dan Recycle Melalui Bank Sampah dan Rencana Strategis Dinas Lingkungan Kabupaten Bandung Barat [3].

\subsection{Evaluasi Penilaian pada Bank Sampah Sahdu}

Evaluasi penilaian pada BSS dilakukan dengan menggunakan metode indeks bank sampah. Metode tersebut memiliki 3 komponen utama, 13 indikator dan 55 sub-indikator [11] yang dapat dilihat pada Tabel 1. Metode indeks bank sampah digunakan untuk melakukan penilaian terhadap bank sampah yang dijadikan subjek perencanaan dengan cara menghitung nilai pembobotan setiap indikator. Nilai pembobotan tersebut kemudian dijadikan acuan untuk merencanakan pengembangan bank sampah. Selanjutnya nilai pembobotan setiap indikator diolah lebih lanjut menggunakan metode agregasi yang merupakan penggabungan nilai untuk memperoleh nilai akhir dari sebuah indeks [12]. Dilakukan dengan cara menentukan nilai-nilai sub-indikator, kemudian digunakan untuk mendapatkan nilai-nilai komponen. Selanjutnya, nilai-nilai komponen dikumpulkan untuk memperoleh nilai indeks akhir [13].

Sebelumnya dilakukan penyesuaian terhadap metode index yang digunakan pada penelitian ini, karena metode indeks yang akan menjadi acuan adalah untuk skala kelurahan, bukan untuk skala kota. Beberapa penyesuaian yang dilakukan yaitu meliputi: sub indikator jumlah nasabah, sub indikator penanganan limbah B3 rumah tangga, sub indikator jenis pengolahan sampah anorganik, dan sub indikator jenis pengolahan sampah organik (Tabel 1). Berdasarkan indeks bank sampah yang telah disusun, maka penentuan hasil pembobotan indeks menggunakan persamaan berikut:

$$
I=\sum_{i=1}^{N} w i S i
$$

Dimana :
I = Nilai penggabungan indeks
$\mathrm{N}=$ Jumlah indikator yang digabungkan
$\mathrm{S}_{\mathrm{i}} \quad=$ sub-indeks untuk indikator $\mathrm{i}$
$\mathrm{w}_{\mathrm{i}} \quad=$ nilai pembobotan dari indikator $\mathrm{i}$ 
Tabel 1. Modifikasi metode indek bank sampah

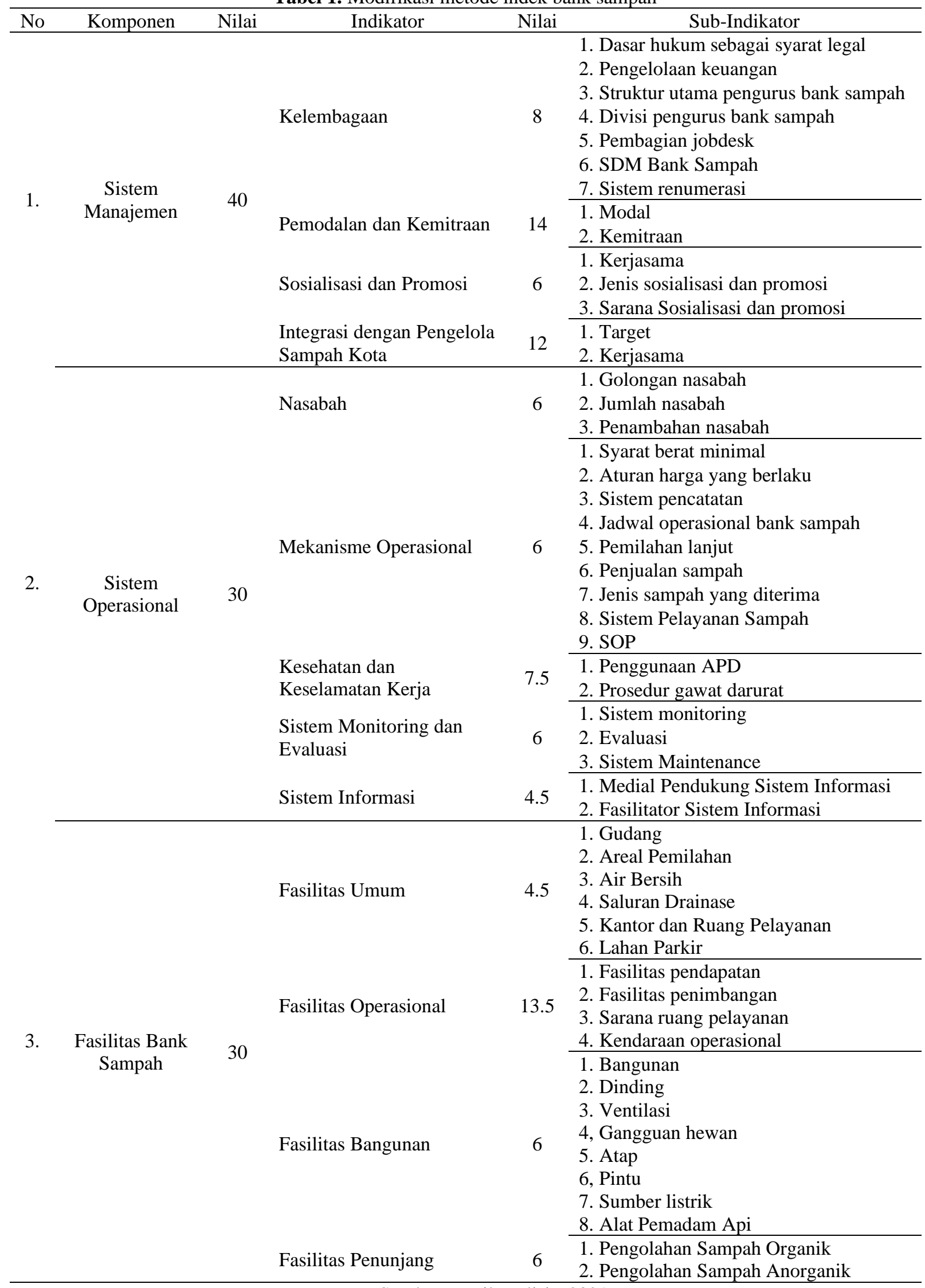

Sumber: Hasil analisis, 2021

\subsection{Interpretasi Indeks}

Berdasarkan Tabel 2, interpretasi indeks dalam studi ini memiliki 5 tingkatan interpretasi [14]. Penetapan lima tingkatan interpretasi dilakukan untuk memberikan gambaran yang lebih rinci terkait 
kondisi bank sampah sebagai obyek studi. Selain itu, dengan penetapan lima tingkatan interpretasi maka rentang antar interpretasi tidak jauh sehingga akan lebih besar juga peluang untuk mendapatkan hasil interpretasi yang baik.

Tabel 2. Interpretasi indeks

\begin{tabular}{cc}
\hline Agregasi Indeks & Interpretasi \\
\hline $0-<25$ & Sangat Buruk \\
$25-<40$ & Buruk \\
$40-<60$ & Cukup \\
$60-<80$ & Baik \\
$80-100$ & Baik Sekali \\
\hline \multicolumn{2}{c}{ Sumber: $[11]$}
\end{tabular}

\subsection{Pengembangan Bank Sampah}

Pengembangan bank sampah yang dilakukan pada perencanaan ini merupakan pengembangan bank sampah dari skala RW menjadi skala kelurahan. Pengembangan dilakukan agar BSS dapat memberikan kontribusi lebih terhadap pengurangan timbulan sampah di Kabupaten Bandung Barat. Pengembangan bank sampah dilakukan berdasarkan indikator yang dinilai belum memenuhi dan belum sesuai berdasarkan kondisi eksisting, selanjutnya dianalisa dan disusun rencana rekomendasi untuk peningkatan kinerja Bank Sampah Sahdu menuju bank sampah skala kelurahan.

\section{Hasil dan Pembahasan}

\section{Evaluasi Penilaian Bank Sampah Sahdu}

Evaluasi penilaian pada BSS dengan menggunakan metode indeks bank sampah dilakukan berdasarkan hasil dari pengumpulan data di lapangan dengan cara observasi dan wawancara, dimana terdapat beberapa kriteria penilaian yang harus disesuaikan dengan kondisi eksisting. Evaluasi penilaian dilakukan berdasarkan 3 komponen yaitu komponen sistem manajemen, sistem operasional, dan fasilitas bank sampah.

\section{a. Penilaian Komponen Sistem Manajemen}

Sistem manajemen memiliki peran penting dalam keberhasilan suatu usaha atau program didalamnya. Sistem manajemen memiliki 4 indikator yaitu kelembagaan, pemodalan dan kemitraan, sosialisasi dan promosi, serta integrasi dengan pengelola sampah kota.

\section{b. Penilaian Indikator Kelembagaan}

Penilaian indikator kelembagaan dilakukan berdasarkan sub-indikator antara lain, dasar hukum sebagai syarat legalitas, pengelolaa keuangan, struktur organisasi pengurus bank sampah, divisi pengurus bank sampah, pembagian jobdesk, SDM bank sampah dan sistem renumerasi. Penilaian yang dilakukan pada sub-indikator dapat dilihat pada Tabel 3.

Tabel 3. Penilaian indikator kelembagaan

\begin{tabular}{|c|c|c|c|c|c|c|c|c|}
\hline \multirow{2}{*}{ Komponen } & \multirow{2}{*}{$\begin{array}{c}\text { Nilai } \\
\text { Maks } \\
\text { K }\end{array}$} & \multirow{2}{*}{ Indikator } & \multirow{2}{*}{$\begin{array}{l}\text { Nilai } \\
\text { Maks I }\end{array}$} & \multirow{2}{*}{ Sub-Indikator } & \multirow{2}{*}{$\begin{array}{l}\text { Nilai } \\
\text { Maks SI }\end{array}$} & \multirow{2}{*}{$\begin{array}{c}\text { Hasil } \\
\text { Observasi }\end{array}$} & \multicolumn{2}{|c|}{$\begin{array}{c}\text { Nilai Bank Sampah } \\
\text { Sahdu } \\
\end{array}$} \\
\hline & & & & & & & SI & I \\
\hline $\mathrm{a}$ & $\mathrm{b}$ & c & $\mathrm{d}$ & $\mathrm{e}$ & $\mathrm{f}$ & $\mathrm{h}$ & $\mathrm{i}=\mathrm{hxf}$ & $\mathrm{j}=\Sigma \mathrm{i}$ \\
\hline \multirow{7}{*}{$\begin{array}{c}\text { Sistem } \\
\text { Manajemen } \\
(40 \%)\end{array}$} & \multirow{7}{*}{40} & \multirow{7}{*}{$\begin{array}{l}\text { Kelembagaan } \\
\quad(20 \%)\end{array}$} & \multirow{7}{*}{8} & $\begin{array}{l}\text { 1. Dasar hukum sebagai } \\
\text { syarat legal }(14,3 \%)\end{array}$ & 1,14 & $100 \%$ & 1,14 & \multirow{7}{*}{6,27} \\
\hline & & & & $\begin{array}{l}\text { 2. Pengelolaan keuangan } \\
(14,3 \%)\end{array}$ & 1,14 & $100 \%$ & 1,14 & \\
\hline & & & & $\begin{array}{l}\text { 3. Struktur utama pengurus } \\
\text { bank sampah }(14,3 \%)\end{array}$ & 1,14 & $100 \%$ & 1,14 & \\
\hline & & & & $\begin{array}{l}\text { 4. Divisi pengurus bank } \\
\text { sampah }(14,3 \%)\end{array}$ & 1,14 & $50 \%$ & 0,57 & \\
\hline & & & & $\begin{array}{l}\text { 5. Pembagian jobdesk } \\
(14,3 \%)\end{array}$ & 1,14 & $50 \%$ & 0,57 & \\
\hline & & & & $\begin{array}{l}\text { 6. SDM bank sampah } \\
(14,3 \%)\end{array}$ & 1,14 & $50 \%$ & 0,57 & \\
\hline & & & & 7. Renumerasi $(14,3 \%)$ & 1,14 & $100 \%$ & 1,14 & \\
\hline
\end{tabular}

Sumber: Hasil analisis, 2021

Contoh perhitungan Indikator Kelembagaan sub indikator dasar hukum sebagai syarat legal sebagai berikut:

$I=\sum_{i=1}^{N} w i S i$ 
Dimana:

$\mathrm{I}=$ Nilai penggabungan indeks

$\mathrm{N}=$ Jumlah indikator yang digabungkan

$\mathrm{S}_{\mathrm{i}}=$ sub-indeks untuk indikator $\mathrm{i}$

$\mathrm{W}_{\mathrm{i}}=$ nilai pembobotan dari indikator $\mathrm{i}$

Nilai maksimal komponen $=$ bobot maks komponen $\mathrm{x} 100$

$=40 \% \times 100=40$

Nilai maksimal indikator $\left(\mathrm{w}_{\mathrm{i}}\right) \quad=$ bobot maks indikator $\mathrm{x}$ nilai maks komponen

$=20 \% \times 40=8$

Nilai maks sub indikator $\quad=$ bobot maks sub indikator $\mathrm{x}$ nilai maks indikator

$=14,3 \% \times 8=1,14$

Nilai sub indikator $\left(\mathrm{S}_{\mathrm{i}}\right) \quad=$ hasil observasi $\mathrm{x}$ nilai maks sub indikator

$\begin{array}{ll}\text { Nilai indikator (I) } & =100 \% \times 1 \\ & =\sum w i S i\end{array}$

$=1,14+1,14+1,14+0,57+0,57+0,57+1,14$

$=6,27$

Tabel 4. Penilaian komponen sistem manajemen

\begin{tabular}{lcc}
\hline \multicolumn{1}{c}{ Indikator } & $\begin{array}{c}\text { Nilai Maks } \\
\text { Indikator }\end{array}$ & $\begin{array}{c}\text { Nilai Bank } \\
\text { Sampah Sahdu }\end{array}$ \\
\hline Kelembagaan & 8 & 6,27 \\
Pemodalan dan kemitraan & 14 & 1,75 \\
$\begin{array}{l}\text { Sosialisasi dan Promosi } \\
\text { Integrasi dengan pengelola }\end{array}$ & 6 & 5 \\
sampah kota & 12 & 3 \\
Total & 40 & 16,02 \\
\hline
\end{tabular}

Sumber: Hasil analisis, 2021

Berdasarkan penilaian pada komponen sistem manajemen (Tabel 4), nilai yang di dapatkan BSS adalah 16,02 dari nilai maksimal komponen sistem manajemen sebesar 40. Hal yang signifikan mempengaruhi penilaian pada komponen sistem manajemen adalah indikator pemodalan dan kemitraan yang memperoleh nilai 1,75 dari 14. Hal ini dikarenakan nilai dari 4 indikator pada sub indikator integrasi dengan pengelola sampah kota, bernilai nol terkait kondisi eksisting BSS.

a. Penilaian Komponen Sistem Operasional

Sistem operasional memiliki peran penting dalam keberlangsungan suatu kegiatan atau usaha karena sistem operasional merupakan pusat dari setiap kegiatan. Sistem operasional memiliki 5 indikator yaitu nasabah, mekanisme operasional, kesehatan dan keselamatan kerja, sistem monitoring dan evaluasi, serta sistem informasi.

Tabel 5. Rekapitulasi penilaian komponen sistem operasioanal

\begin{tabular}{lcc}
\hline \multicolumn{1}{c}{ Indikator } & $\begin{array}{c}\text { Nilai Maks } \\
\text { Indikator }\end{array}$ & $\begin{array}{c}\text { Nilai Bank Sampah } \\
\text { Sahdu }\end{array}$ \\
\hline Nasabah & 6 & 2 \\
Mekanisme Operasional & 6 & 4,9 \\
Kesehatan dan & 7,5 & 1,88 \\
$\begin{array}{l}\text { Keselamatan Kerja } \\
\text { Sistem Monitoring dan }\end{array}$ & 6 & 2 \\
$\begin{array}{l}\text { Evaluasi } \\
\text { Sistem Informasi }\end{array}$ & 4,5 & \\
Total & 30 & 3,8 \\
& Sumber: Hasil analisis, 2021 \\
\hline
\end{tabular}

Sumber: Hasil analisis, 2021

Berdasarkan Tabel 5 nilai yang diperoleh untuk komponen sistem operasional adalah 15,38 hal ini dikarenakan oleh nilai pada indikator kesehatan dan keselamatan kerja adalah sebesar 1,88 (dengan persentase sebesar 25\% dari 5 indikator penilaian). Penilaian pada sub-indikator prosedur gawat darurat adalah nol terkait kondisi eksisting BSS sehingga signifikan terhadap nilai akhir yang diperoleh. 


\section{b. Penilaian Terhadap Komponen Fasilitas Bank Sampah}

Fasilitas Bank Sampah memiliki peran penting dalam keberlangsungan suatu kegiatan atau usaha karena merupakan penunjang terhadap kegiatan bank sampah [15]. Fasilitas bank sampah memiliki 4 indikator yaitu fasilitas umum, fasilitas operasional, fasilitas bangunan, dan fasilitas penunjang.

Tabel 6. Rekapitulasi penilaian komponen fasilitas bank sampah

\begin{tabular}{lcc}
\hline \multicolumn{1}{c}{ Indikator } & Nilai Maks Indikator & Nilai Bank Sampah Sahdu \\
\hline Fasilitas Umum & 4,5 & 4,5 \\
Fasilitas Operasional & 13,5 & 6,75 \\
Fasilitas Bangunan & 6 & 4,5 \\
Fasilitas Penunjang & 6 & 6 \\
\hline Total & 30 & 21,75 \\
\hline
\end{tabular}

Sumber: Hasil analisis, 2021

Berdasarkan Tabel 6 nilai yang yang diperoleh adalah 21,75, hal ini terkait nilai indikator pada fasilitas operasional adalah 6,75 (dengan persentase terbesar yaitu $45 \%$ dari 4 indikator). Belum lengkapnya fasilitas operasional pada sub-indikator sarana ruang pelayanan dan kendaraan operasional yang memiliki nilai nol, sehingga akan mempengaruhi secara langsung terhadap nilai total untuk komponen fasilitas bank sampah.

\section{Rekapitulasi Penilaian Indeks Bank Sampah}

Berdasarkan Tabel 7 nilai keseluruhan indeks bank sampah yang diperoleh adalah sebesar 52,7. Hal tersebut dipengaruhi oleh beberapa sub indikator dari setiap komponen yang tidak memiliki nilai sehingga berpengaruh terhadap penilaian indeks bank sampah. Nilai 52,7 termasuk dalam kategori cukup baik berdasarkan interpretasi indeks dapat dilihat pada Tabel 2.

Tabel 7. Rekapitulasi penilaian indeks bank sampah

\begin{tabular}{|c|c|c|c|}
\hline Komponen & $\begin{array}{l}\text { Nilai Maks } \\
\text { Komponen }\end{array}$ & $\begin{array}{c}\text { Nilai Bank } \\
\text { Sampah Sahdu }\end{array}$ & $\begin{array}{c}\text { Target Pengembangan } \\
\text { Bank Sampah Sahdu }\end{array}$ \\
\hline Sistem manajemen & 40 & 16,02 & 34,16 \\
\hline Sistem Operasional & 30 & 14,9 & 25,6 \\
\hline Fasilitas Bank Sampah & 30 & 21,75 & 28,5 \\
\hline Total & 100 & 52,7 & 88,3 \\
\hline
\end{tabular}

\section{Rekomendasi}

Rekomendasi dilakukan pada komponen sistem manajemen, komponen sistem operasional, dan komponen fasilitas berdasarkan hasil penilaian indeks bank sampah yang dilakukan seperti yang dijelaskan pada Tabel 8.

Tabel 8. Rekomendasi meningkatkan penilaian interpretasi indeks

\begin{tabular}{|c|c|c|c|c|c|}
\hline No. & Komponen & $\begin{array}{c}\text { Nilai } \\
\text { Komponen }\end{array}$ & $\begin{array}{c}\text { Target } \\
\text { Pengembangan }\end{array}$ & $\begin{array}{c}\text { Sub } \\
\text { Indikator }\end{array}$ & Usaha yang dilakukan \\
\hline 1. & Sistem & 16,02 & 34,16 & $\begin{array}{l}\text { Divisi } \\
\text { Pengurus } \\
\text { Bank } \\
\text { Sampah }\end{array}$ & $\begin{array}{l}\text { Terdapat Divisi Pengembangan yang } \\
\text { memiliki tugas melakukan terobosan } \\
\text { dalam merancang strategi bank sampah } \\
\text { seperti kenaikan jumlah nasabah, } \\
\text { pembuatan website dan melakukan kerja } \\
\text { sama dengan pihak lain untuk } \\
\text { mendukung kegiatan bank sampah. }\end{array}$ \\
\hline 2. & anajemen & 16,02 & 34,16 & $\begin{array}{l}\text { Pembagian } \\
\text { Jobdesk }\end{array}$ & $\begin{array}{l}\text { Adanya SOP serta pembagian jobdesk } \\
\text { yang jelas untuk setiap anggota } \\
\text { pengurus yang terlibat dan serta } \\
\text { peningkatan pemahaman operasional } \\
\text { oleh seluruh anggota pengurus melalui } \\
\text { pelatihan majerial, serta didukung } \\
\text { system yang trasparan [16] }\end{array}$ \\
\hline 3. & & 16,02 & 34,16 & Modal & $\begin{array}{l}\text { Melakukan kerja sama dengan } \\
\text { pemerintah terkait seperti kelurahan } \\
\text { dan Dinas Lingkungan Hidup untuk } \\
\text { mendukung kebutuhan operasional. }\end{array}$ \\
\hline
\end{tabular}




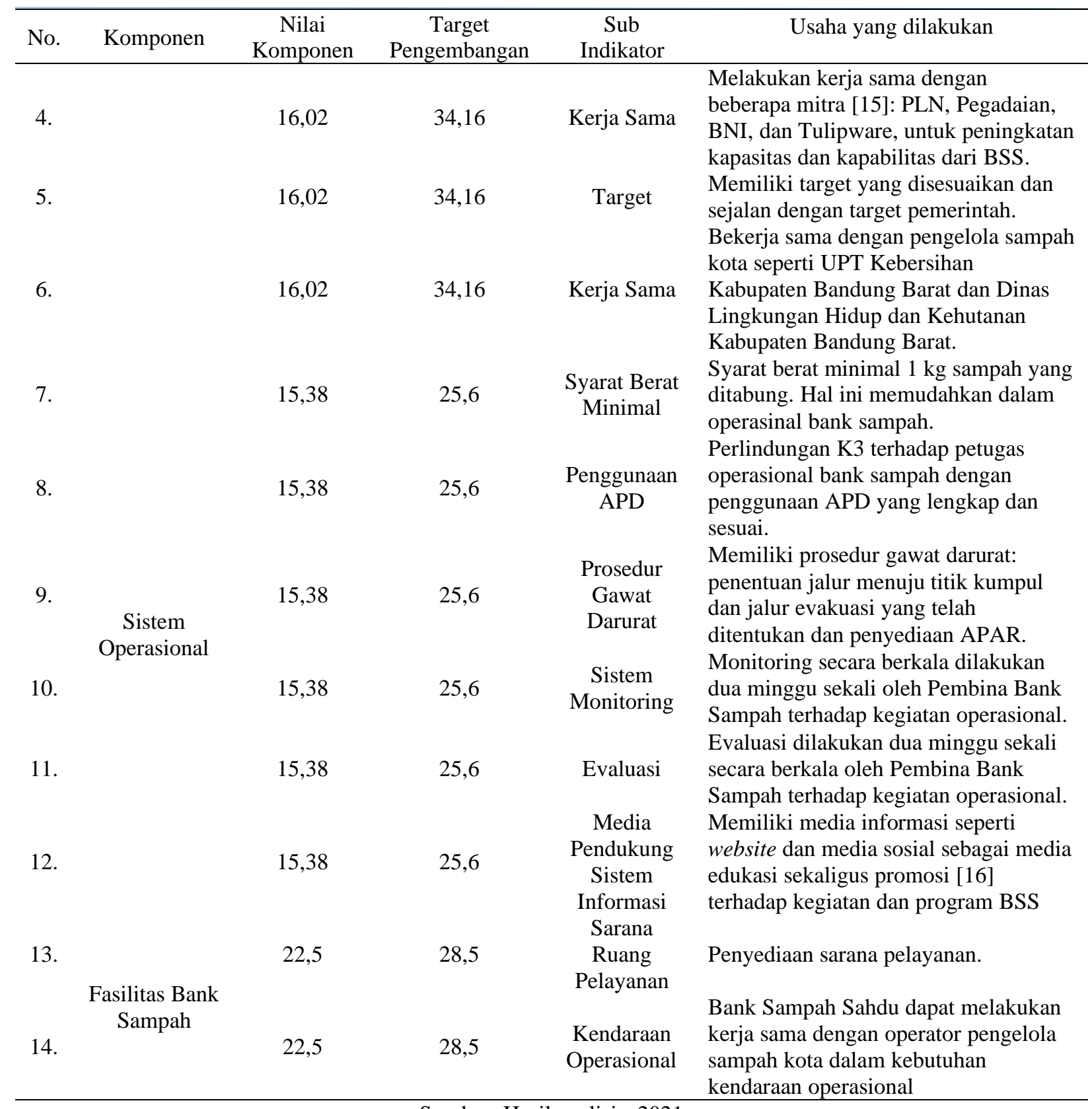

\section{a. Tempat Penyimpanan Sampah}

Bank Sampah Sahdu memiliki luas tempat penyimpanan sampah sebesar $9 \mathrm{~m}^{2}$ yang dapat menampung $250 \mathrm{~kg}$ sampah. Adapun jumlah nasabah Bank Sampah Sahdu eksisting adalah sebanyak 50 nasabah dengan jadwal penjualan sampah dilakukan dua bulan sekali terkait kapasitas tempat penyimpanan sampah. Direncanakan adanya peningkatan nasabah yang semula 50 menjadi 600 nasabah berdasarkan kapasitas penyimpanan sampah yang ada dan pengaturan penjualan sampah dengan pihak pengepul yaitu 3 kali seminggu dengan total 2,4 ton sampah per bulannya.

b. Pola Pengambilan Sampah Nasabah

Sistem penabungan nasabah yang akan dilakukan Bank Sampah Sahdu adalah melalui dua cara yaitu nasabah menabung secara langsung ke bank sampah dan yang kedua adalah pengambilan sampah nasabah oleh pengelola Bank Sampah Sahdu. Hal ini dilakukan bagi nasabah yang rumahnya berada disekitar wilayah lokasi bank sampah, yaitu yang berada di RW 21, RW 22, dan RW serta bekerja sama dengan petugas pengangkut sampah. Upaya memfasilitasi para nasabah akan meningkatkan partisipasi masyarakat, yang merupakan elemen penting dari eksistensi dan keberlangsungan bank sampah [17]. Terkait hal tersebut, dibutuhkannya kendaraan operasional untuk pengambilan sampah dari setiap rumah nasabah. 
Adapun pola pengambilan sampah yang direncanakan adalah dengan pengaturan jadwal pengambilan sampah di setiap RW per-harinya, seperti yang terlihat pada Gambar 1.

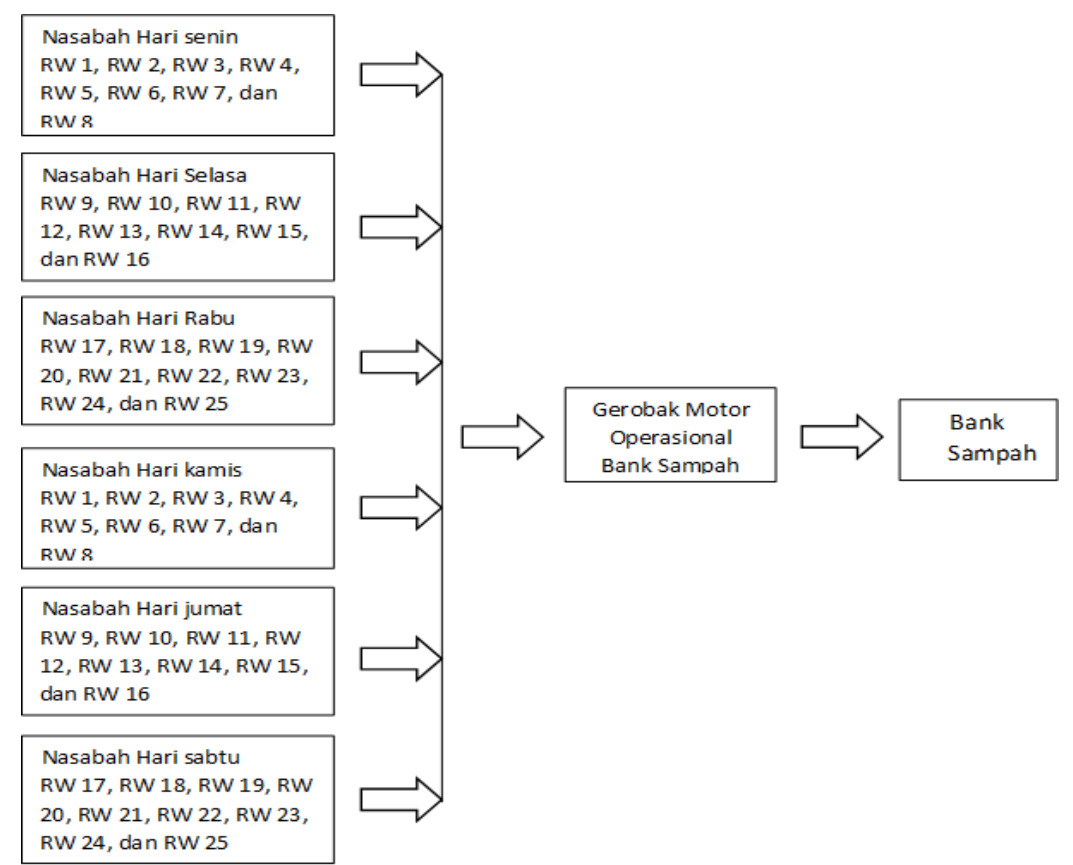

Gambar 1. Pola pengumpulan sampah dari nasabah Sumber: Hasil analisis, 2021

\section{c. Pengurangan Sampah berdasarkan aktifitas Bank Sampah Sahdu}

Timbulan sampah diperoleh berdasarkan proyeksi timbulan sampah untuk Tahun 2022 adalah 262,9 ton/bulan berdasarkan data proyeksi jumlah penduduk dan timbulan sampah. Pengurangan sampah dihitung berdasarkan pengolahan sampah organik dan penjualan sampah anorganik yang dilakukan BSS. Pengolahan sampah organik yang dilakukan menggunakan bata tarawang untuk menghasilkan kompos. Bank Sampah Sahdu memiliki 12 buah bata tarawang yang tersebar di RW 22, sehingga kapasitas pengolahan sampah organik adalah 1,6 ton/bulan berdasarkan kemampuan serta kapasitas 1 bata tarawang dapat mengolah sampah organik sebesar $130 \mathrm{~kg}$ [7].

Selanjutnya potensi pengurangan sampah anorganik BSS yang diperoleh dari tabungan sampah sejumlah 600 nasabah adalah sebesar 2,4 ton/bulan. Sehingga total pengurangan sampah yang dapat dilakukan BSS adalah sebesar 4 ton/bulan atau sebesar 1,6\% dari total proyeksi timbulan sampah Desa Tanimulya pada Tahun 2022. Lebih jelasnya, neraca persentase pengurangan sampah dapat dilihat pada Gambar 2.

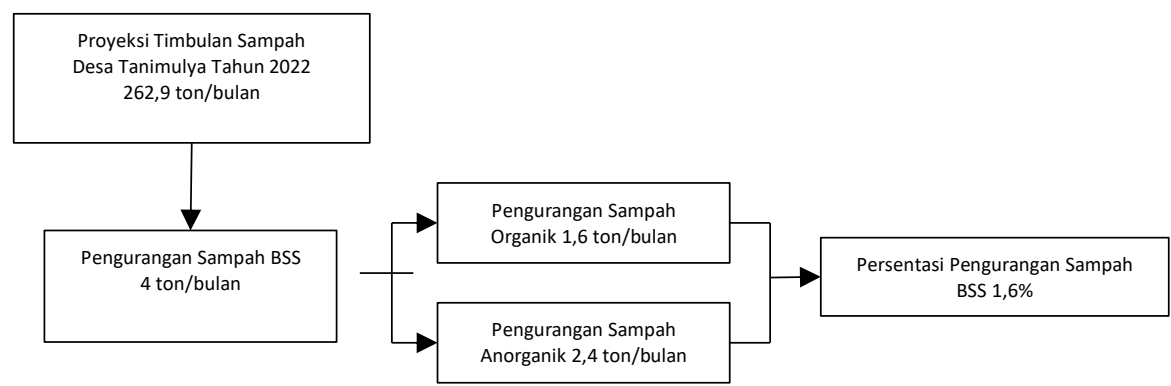

Gambar 2. Neraca persentase pengurangan sampah Bank Sampah Sahdu Sumber: Hasil analisis, 2021

\section{Kesimpulan}

Pengembangan BSS menjadi skala kelurahan dilakukan dengan meningkatkan nilai index bank sampah yang semula 52,7 menjadi 88,3 melalui rekomendasi terhadap 14 sub indikator penilaian dari komponen yaitu: Sistem Manajemen sebanyak 6 sub indikator, Sistem Operasional sebanyak 6 sub indikator dan Fasilitas Bank Sampah sebanyak 2 sub indikator. Melalui pengembangan ini tingkat pengurangan sampah menjadi 4 ton/bulan dari $150 \mathrm{~kg} / \mathrm{bulan}$ atau meningkat sebesar 266,67\%. Kontribusi 
BSS terhadap pengurangan sampah untuk seluruh Kabupaten Bandung Barat adalah sebesar 1,6\% dari target 10\% berdasarkan Rencana Strategis Dinas Lingkungan Hidup Kabupaten Bandung Barat Tahun 2019.

\section{Daftar Pustaka}

[1] Menteri Negara Lingkungan Hidup Republik Indonesia, "Peraturan Menteri Negara Lingkungan Hidup Republik Indonesia Nomor 13 Tahun 2012 Tentang Pedoman Pelaksanaan Reduce, Reuse, dan Recycle Melalui Bank Sampah,” 2013.

[2] D. R. Wijayanti and S. Suryani, "Waste Bank as Community-based Environmental Governance: A Lesson Learned from Surabaya," Procedia - Soc. Behav. Sci., vol. 184, no. August 2014, pp. 171179, 2015, doi: 10.1016/j.sbspro.2015.05.077.

[3] DLH kabupaten Bandung Barat, "Rencana Strategis 2018 - 2023," Kabupaten Bandung Barat, 2018.

[4] A. Priyo, N. Sulami, T. Murayama, and S. Nishikizawa, "Current Issues and Situation of Producer Responsibility in Waste Management in Indonesia," 2018.

[5] D. Wulandari, S. H. Utomo, and B. S. Narmaditya, "Waste bank: Waste management model in improving local economy," Int. J. Energy Econ. Policy, vol. 7, no. 3, pp. 36-41, 2017.

[6] C. J. Rhodes, "Plastic pollution and potential solutions," Science progress, vol. 101, no. 3. NLM (Medline), pp. 207-260, Sep. 01, 2018, doi: 10.3184/003685018X15294876706211.

[7] N. Hasna, I. Juwana, and M. Satori, "Studi Komparasi Komposter Berbasis Masyarakat," J. Reka Lingkung., vol. 9, no. 1, pp. 34-44, 2020, doi: 10.26760/rekalingkungan.v9i1.34-44.

[8] BPS Kabupaten Bandung Barat, "Kecamatan Ngamprah dalam Angka 2018," Kabupaten Bandung Barat, 2018. [Online]. Available: https://bandungbaratkab.bps.go.id.

[9] National Plastic Action Partnership, "Radically Reducing Plastic Pollution in Indonesia: A Multistakeholder Action Plan,” 2020.

[10] Ministry of Environment and Forestry, "National Plastic Waste Reduction Strategic Actions for Indonesia," 2020.

[11] M. Pranaditya, I. Juwana, and S. Ainun, "Pengembangan Indeks Penilaian Bank Sampah Skala Kota Studi Kasus Kota Bandung dan Kota Cimahi," J. Reka Lingkung., vol. 8, no. 2, pp. 121-133, 2020, doi: 10.26760/rekalingkungan.v8i2.121-133.

[12] OECD, Handbook on Constructing Composite Indicators. OECD, 2008.

[13] I. Juwana, "Development of a Water Sustainability Index for West Java, Indonesia," no. March 2012, p. 228, 2012.

[14] K. Saffran, K. Cash, and K. Hallard, "CCME Water Quality Index 1.0 User's Manual," Can. Water Qual. Guidel. Prot. Aquat. Life, pp. 1-5, 2001, [Online]. Available: http://www.ccme.ca/files/Resources/calculators/WQI User's Manual (en).pdf.

[15] H. P. Putra, E. Damanhuri, and E. Sembiring, "Identification of factors affecting the performance of waste bank in waste management system in the 'Kartamantul' Territory (Yogyakarta city, Sleman\ and Bantul districts), special region of Yogyakarta, Indonesia," Pollut. Res., vol. 38, no. March, pp. S94-S99, 2019.

[16] A. P. Triana and E. Sembiring, "Evaluasi Kinerja Dan Keberlanjutan Program Bank Sampah Sebagai Salah Satu Pendekatan Dalam Pengelolaan Sampah Dengan Konsep 3R," J. Tek. Lingkung., vol. 25, no. 1, pp. 15-28, 2019, doi: 10.5614/j.tl.2019.25.1.2.

[17] M. Haqq and I. Warmadewanthi, "Strategi pengembangan bank sampah sebagai upaya peningkatan reduksi sampah di wilayah Surabaya Selatan," Institut Teknologi Sepuluh Nopember, 2018. 